\title{
THE ECONOMIC ASPECT OF SPECIAL \\ PARALLEL RELATIONS BETWEEN THE REPUBLIC SERBIA AND THE REPUBLIC OF SRPSKA IN ACCORDANCE WITH THE DAYTON PEACE AGREEMENT
}

\section{Rajko Tomas ${ }^{41}$}

\begin{abstract}
The General Framework Agreement for Peace (Dayton Peace Agreement) in Bosnia and Herzegovina $(\mathrm{B} \& \mathrm{H})$ gave the right to entities that make $\mathrm{B} \& \mathrm{H}$ to establish special parallel relations with adjoining countries. That possibility was so far used by the Republic of Serbia and the Republic of Srpska, as an entity within B\&H. In this paper, we examine economic aspect of special parallel relations between Serbia and the Republic of Srpska. Demand structure in Serbia and the Republic of Srpska is similar, due to which we have put our analysis in the context of Linder hypothesis. Empirical analysis has confirmed that the two economies have a high level of similarity of export and that they are severe competition in the third markets. Both economies have a high level of economy diversification and a low level of export diversification. According to the logic of Linder hypothesis, economies of Serbia and the Republic of Srpska can use a relatively big potential possibilities of economic cooperation by the increase of specialization in production, i.e. by reducing economy diversification and increasing export diversification. It can be achieved by innovations in development of economies and their differentiation.
\end{abstract}

KEY WORDS: Dayton Peace Agreement, special parallel relations, economic cooperation, Linder hypothesis

JEL: F30

UDC: 339.92(497.11:497.6)

339.94

COBISS.SR-ID 272231180

\footnotetext{
${ }^{41}$ Faculty of Economics, University of Banja Luka, Bosnia and Herzegovina Member of the Academy of Sciences and Arts of the Republic of Srpska, Banja Luka, Bosnia and Herzegovina,e-mail: rajko.tomas@ef.unibl.org
} 


\section{INTRODUCTION}

Dayton Peace Agreement enabled the entities that are integral parts of $\mathrm{B} \& \mathrm{H}$ to obtain internationally verified right to establish special parallel relations with neighbouring countries ${ }^{42}$. Dayton Agreement itself has not determined the nature and intensity of parellel relations with neighbouring countries in details. It remained for the entities and neighbouring countries in the future, using all the options of international law and Dayton Peace Agreement, to establish parallel relations that will promote their cooperation and contribute to the strengthening of peace in the region. Federal Republic of Yugoslavia and Republic of Srpska, and later Republic of Serbia and Republic of Srpska have decided to sign the Agreement on Special Parallel Relations ${ }^{43}$.

Good intentions of Dayton Agreement and Agreement on Special Parallel Relations are impossible without economic development. Precisely for that reason, it is justified to ask the question whether economic relations between Serbia and Srpska have a specific character, having in mind that the Agreement foresees economic cooperation? Whether its scope, intensity and structure was primarily determined by spontaneous motivation of the enterprise on the market or it is affected by devised strategies and incentive and cooperation policies that are carried out by institutions of the two countries?

Today, economic cooperation between Serbia and Srpska, regardless of the Agreement signed, is most frequently developed ina spontaneous manner, according to the motives and possibilities of the interested companies. Spontaneous actions of the market, particularly in conditions when each country, mutually independently, tends to provide its place in European integrations, it is very unlikely that economic structures of the Republic of Srpska and Serbia will be harmonized in a manner that is implied by special parallel relations. In addition, for a better comprehension of economic range of the Agreement, we should remind that the economy of the Republic of Srpska acts within a unique market of $\mathrm{B} \& \mathrm{H}$, and also that the cooperation between the economy of the Republic of Srpska and the economy of the Republic of Serbia has a direct effect on overall economic cooperation between Serbia and B\&H. The impact on cooperation between two economies also has the membership of B\&H and Serbia in CEFTA and the tendency of both countries to become members of the European Union.

\section{SUBJECT AND GOALS OF THE STUDY}

After more than 22 years since signing Dayton Agreement there is no systematized content of special parallel relations in the field of economic cooperation that entities in $\mathrm{B} \& \mathrm{H}$ have a right to with the neighbouring countries. The subject of our study is to determine the similarity and compatibility of economic structure of Serbia and Srpska and to evaluate how realistic are the objective possibilities of establishing, intensifying and spreading economic cooperation and how realistic are the expectations for the economic cooperation to strengthen parallel realtions and

\footnotetext{
42 Article 3. of B\&H Constitution: „Entities will have the right to establish special parallel relations with neighbouring countries in accordance with the sovereignty and territorial integrity of Bosnia and Herzegovina“".

${ }^{43}$ Based on Dayton Agreement, the Republic of Serbia and the Republic of Srpska have signed the Agreement on Special Parallel Relations on 26.09.2006. On the same day when this Agreement entered to force, the Agreement on Special Parallel Relations signed between Federal Republic of Yugoslavia and the Republic of Srpska on the 5th of Marck 2001 in Banja Lika stopped being valid.
} 
thus, indirectly, through unique market of $\mathrm{B} \& \mathrm{H}$, to contribute the promotion of overall cooperation between Serbia and B\&H and establishment of peace in the region.

The aim of the analysis is not to determine the conditions for the establishment of autarchic system, on the contrary, it is the increase of efficiency of using the resources through a wider and more intensive cooperation, then the increase of competitiveness and creation of assumptions for inclusion to a wider free market. Our goal is to provide the governments the elements for creating the strategies of adaptation of economic structures in order to strengthen mutual economic cooperation. We want to verify whether the existing level of mutual cooperation between Serbia and the Republic of Srpska is intensive or extensive, whether if it is based on difefrentiated or homogenized products. This knowledge can be a basis for the creation of a series of specific measures of economic policy that can contribute to the development of both economies.

In classical international exchange, the issues of mutual exchange of countries can be left to the long-term spontaneous equalization through the market. If the economic cooperation of the two countries is carried out exclusively based on economic motivation of the enterprise, its competitiveness, ability to win the market and mutual openness for cooperation, achievement of the interest of idividual enterprises can cause harm to entire activities in one of the countries. High level of competitiveness of certain activity in one country, in conditions of free trade with homogeneous product, can jeopardize the survival of the enterprise in that activity in another country. Outflow of profits from one country to another will jeopardize the development of a poorer country, i.e. the country from which the profit outflows. One of the goals of this analysis is the identification of the mentioned and other obstacles for the development of intensive economic cooperation and discouragement of the carriers of economic policy to reach for the protectionist, dumping or discriminatory measures in trade development.

This analysis attempts, within the framework of market model of economy, in the domain of state impact through the creation of conditions for doing business and leading economic policy, to offer solutions for actions of the governments of Srpska and Serbia in order to encourage mutual cooperation of the enterprises. Free trade between countries, which is precisely the case between the Republic of Srpska, i.e. B\&H, and the Republic of Serbia, is a good environment for the achievement of coordination of measures of economic policy with the aim to use the effects of a wider market for the development of both economies. B\&H and Serbia are important members of CEFTA. This group of countries shares a series of similar characteristics in the structure of demand and implements a series of policies in market liberalization. Their more intensive economic cooperation seems as an incentive for the integration in European Union. In that aspect, Linder hypothesis (Linder, 1961) can become a basis for the establishment of economic dimension of special parallel relations between entities of $\mathrm{B} \& \mathrm{H}$ and neighbouring countries, as well as all members of CEFTA.

\section{HYPOTHESIS OF THE STUDY}

History of economic cooperation reminds that it is not determined primarily by the political will and awareness of its role in realization of that will. On the contrary, economic principles of free market ignore political determinations.

Economic cooperation between two economies is determined by their economic structure. Economic structure of one country is shaped under the impact of absolute and comparative advantages that the producers find in its territory. Lead by maximizing behaviour, market participants make a choice that suits their interests. Their goal is not the realization of a previously determined strategy of economic cooperation with some country. The intensity of economic cooperation between two countries, in conditions of free exchange, primarily depends on 
economic interests of market participants, i.e. the possibility of achieving those interests through the exchange with the participants from the country given.

If the economic structures are similar, but the economies offer differentiated products in the aspect of prices and quality, mutual cooperation is possible and desirable. The logic of this form of economic cooperation between two economies is also contained in Linder hypothesis. According to Linder, ,potential trade in manufactures is most intensive among countries with similar demand structures, i.e., countries with about the same per capita income levels" (Linder, 1961, pp. 107).

The fact is that Serbia and the Republic of Srpska, as well as entire B\&H, have a similar structure of demand and an approximately equalized level of income per capita ${ }^{44}$. According to Linder hypothesis, they have potential possibilities for development of a rather intensive trade if they produce differentiated products. This conclusion is precisely a basic hypothesis of this study. Linder hypothesis is a good theoretical basis for economic dimension of special parallel relations of $\mathrm{B} \& \mathrm{H}$ entity with neighbouring countries both when it is confirmed and rejected by empirical studies. When it is confirmed, that it is mutually traded with differentiated products and that it should be continued with the incentive policy of product differentiation, and when it is not confirmed that, in the interest of mutual economic development, we should apply the strategy of differentiation and development encouragement based on differentiated products. Our analysis aims at explaining that Linder hypothesis does not imply that economic cooperation should be stopped if two countries produce homogeneous products. On the contrary, our goal is to show that in this case the governments should lead the incentive policy of product differentiation, which will aim at the increase of mutual exchange and achievement of growth in both economies.

\section{LITERATURE REVIEW}

More serious and comprehensive studies on economic cooperation between economies of Serbia and Srpska do not exist. Mainly, in serious references, this cooperation is observed in the context of economic cooperation between the countries that originated after the decomposition of SFRY (Madžar at all, 2000), economic cooperation of Western Balkan countries on the path to European integrations (Penev, 2013; Penev and Marusic, 2011; European Commission, 2009; Kathuria, 2008) or extension of sectoral cooperation in the region (Stojković, 2012). There is no study that mentions special parallel relations of B\&H entity with neighbouring countries and the manner of their achievement, although they have full legitimacy based on internationally verified peace agreement.

As our goal is not to verify whether Linder hypothesis is confirmed or not in mutual trade between Serbia and the Republic of Srpska, but the assessment whether the existing level and structure of trade contribute to the strengthening of special parallel relations, we will not go any deeper in excessive literature which resulted because of Linder's criticism of Heckscher-OhlinSamuelson (HOS model) (Heckscher, 1919; Ohlin, 1933; Samuelson, 1948) theory of international exchange, based on Leontief's paradox (Leontief, 1953). HOS model comes from the assumption that international trade determined by relative structure of product factors, i.e. differences in relative prices of goods that are derived from relative differences of the work and capital relations. According to that, countries with a higherrelative share of capital will export

\footnotetext{
${ }^{44}$ GDP per capita, by the purchasing power parity (PPP), 2016. in Serbia was 13720,09 US \$, and in B\&H 11179,35 US \$ (source: https://tradingeconomics.com/serbia/gdp-per-capita-ppp, 5.6.2018). In the same year, GDP per capita of Serbia was 5426,2 US \$, B\&H 4808,4 US \$, and the Republic of Srpska 4706 US \$ (source: https://data.worldbank.org/indicator/NY.GDP.PCAP.CD, 12.6.2018).
} 
capital-intensive products and the countries with a higher relative share of work work-intensive products. Leontief's analysis from 1953. has shown, in the example of export and importa of USA 1947., that the import from the USA is on average relatively work-intensive and the import is relatively capital-intensive, i.e. if relative relation capital/work is reduced, export makes a greater and import relatively smaller part of foreign trade circulation (Leontief, 1953, pp. 346).

Linder observes (Linder, 1961, pp. 15) that HOS model implies general law of international labour division according to which each country tends to export goods for whose production it uses own available resources, a country cannot achieve comparative advantage in the production of some good if there is no demand for it in the domestic market. „To the extent in which the income per capita determines the structure of demand, the trade between the countries will be more intensive" (Linder, 1961, pp. 17). This is entrely the opposite to the setting of HOS model, where the differences in relative relation of capital and work per capita are the basis of differences in the structure of demand and relative prices. The bigger the differences, the greater the space for trade.

Linder hypothesis has become the subject of verification in the trade of a greater number of countries. The study published in 1973. (Sailors et al, 1973, pp. 268) has shown that the industrial products trade is more intensive between countries when their internal structure of demand is more similar. However, the authors reach the conclusion that similarity of income per capita is not sufficient for explaining international trade in global proportions. They believe that the analysis should include other factors such as constraints to the exchange, tariff barriers, transport costs, market vicinity...On the example of international trade of Bangladesh, India and Pakistan (Bukhari et al, 2005), the activity of Linder hypothesis was confirmed, i.e. it was shown that these countries achieve more intensive trade with countries from other regions which have a similar level of income per capita. Analysis of international trade for 19 countries of OECD (Mcpherson et al, 2006) has confirmed the justification of of Linder hypothesis in case of 18 countries.

An interesting confirmation of Linder hypothesis was reached by Alison Rauh (Rauh, 2010) analyzing international exchange of Germany, as a leading economy within European Union. According to this analysis, Germany achieves more intensive trade with countries with a similar level of income per capita, so the German exportwithin European Union is primarily aimed towards countries with a similar demand structure.

Hallak's study from 2010 (Hallak, 2010), based on sectoral gravity model, has shown a limited range of Linder hypothesis. It is formally derived and sustainable only if it is formulated at sector level where there is a possibility to control intersectoral determinants of trade.

In 2014, Kahram has, by analyzing foreign trade and GDP per capita level of Iran and partner countries, shown that there is a strong Linder effect in bilateral trade of Iran (Kahram, 2014). Indeed, it was shown that Linder effect is not the only factor that determines the scope and directions of foreign trade of Iran. A great impact to directions and intensity of foreign trade, in this case, have: politics and ideology; international sanctions, political instability, economic strength of trade partners, distance between countries, length of common border...

Countries of Southeastern Europe, although with an expressed similarity of demand structure, according to the analysis of Monica Moraliyske (Moraliyska, 2015), have a low level of mutual trade, significantly below potential possibilities for neighbouring countries. Existing level of cooperation is mainly of institutional nature and less essential. Southeastern Europe countries realize more intensive trade with the European Union countries that with each other. Obviously, market of the Union offers greater business possibilities, so the countries of Southeastern Europe, as potential members of the Union, tend to strengthen their economic relations with the Union rather them between each other.

The verification of Linder hypothesis on the examples of foreign direct investments for the countries with a different level of income per capita was done by P. Fajgelbaum, G. Grossman 
and E. Helpman (Fajgelbaum, 2014). Their analysis has shown that there is a greater probability of the origination of foreign direct investments between countries with a similar level of income per capita.

One part of the papers on the verification of Linder hypothesis was aimed towards the analysis of trade with certain products. Based on the same on trade with 737 agricultural and food products from 152 countries, Steinbach (Steinbach, 2015) has, by using the adapted Hallak's sectoral gravity model (Hallak, 2010), shown that similarity of aggregate preferences has a strong impact on the movement of mutual trade by products intended for final consumption. Similarity of aggregate preferences is the strongest in case of final and the weakest in case of products in bulk state. The intensity of mutual trade by these products corresponds with the similarity of preferences. Linder hypothesis has also obtained the confirmation on the example of the differentiated products trade analysis (Niem, 2016).

\section{RESEARCH METHODS}

In accordance with the goal and hypothesis of the research, we will tend, from different aspects, to analyze the existing scope and structure of mutual trade of the economies of Serbia and Srpska. For that reason, we will determine the values of different indicators that will serve as a basis for making conclusions on tendencies, state and structure of foreign trade based on which we will define recommendations for the policy of aiming foreign trade. For the needs of analysis in this study, we will use the following indicators (Mikic and Gilbert, 2007): Finger-Kreinin index (The Export Similarity Index), Complementarity Index, Coefficient of Conformity, Regional Trade Intensity Index, Openness Index or Trade Dependence Index, Main export product index, Hirschman's index of regional concentration of export, Export diversification index, Sectoral index of intra-industrial trade and Trade overlap index.

The basis for calculation of the values of indicators mentioned are the data of republic bureaus of statistics of the Republic of Srpska and Serbia on the scope and structure of commodity exchange of the Republic of Srpska and Serbia in the period from 2008-2012., classified according to Standard International Trade Classification (SITC, Revision 3, 1988).

1. Finger-Kreinin index (Finger and Kreinin, 1979) measures silimarity of the structure of export of the two countries. If the two economies have a greater value of export similarity index, there is greater probability that those countries are competitors in the global market. In addition, high value of the index implies that there is a relatively small space for international foreign trade cooperation.

Finger-Kreinin index $(S$ or $F K$ ) is calculated according to the following pattern:

$S=\left\{\sum_{i}\right.$ Minimum $\left.\left[\frac{X_{i j}}{\sum X_{i j}}, \frac{X_{i k}}{\sum X_{i k}}\right]\right\} 100$

where:

$X_{i j} / \Sigma X_{i j}$ - is the share of export (import) of products $i$ in the total export (import) of the country $j, X_{i k} / \Sigma X_{i k}$ - share of export (import) of products $i$ in the total export (import) of the country $k$.

Value of Finger-Kreinin index varies in the range $[0,100]$. If the value of the index is 0 , in trade of the countries $j$ and $k$ there is a complete structural diversity of export (import), and if it is 100 , there is a complete structural similarity of export (import). If for every $i$ it is $X_{i j}=X_{i k}$, the 
index has a maximum value. If the values $X_{i j}$ and $X_{i k}$ are entirely different, i.e. if for each $X_{i j}>0$, $X_{i k}=0$ and vice versa, the index will have 0 value. Therefore, if the difference between the share of particular commodity groups in the total export (import) of the countries $j$ and $k$ is big, index value will be closer to zero. If the index value is minimal $(0)$, it means that in the structure of export (import) of the country $k$ there is no product that exists in the structure of export (import) of the country $j$, and vice versa. Extreme values of Finger-Kreinin index are rarely verified in empirical studies.

2. Complementarity index $\left(I_{c}\right)$ is in the group of complementarity measures, i.e. overlap of export (import) of the two countries. It measures the complementarity level of export structure of one country with the structure of the import of the other country. High level of complementarity shows greater chances for establishment of successful trade exchange between two countries, and vice versa. Changes in values of the complementarity index over the time show whether trade structure of the countries analyzed strengthens or reduces the compatibility of trade exchange.

The index is calculated by substracting from the unit of absolute value of the half sum of differences of share of the $i$-goods export in the total export of one country and share of import of $i$-goods in the total import of another country, i.e.:

$$
I_{c}=1-\frac{1}{2}\left|\frac{X_{i j}^{e}}{\sum_{i=1}^{n} X_{i j}^{e}}-\frac{X_{i k}^{i}}{\sum_{i=1}^{n} X_{i k}^{i}}\right|
$$

Where $X_{i j}{ }^{e}$ is the export of $i$-goods of the country $j$, and $X_{i k}{ }^{i}$ is the import of $i$-goods of the country $k$.

Index value moves in the range $(0,1)$, i.e. $(0,100)$. If the value of index is minimal $\left(I_{c}=0\right)$, it means that export of $i$-goods of the country $j$ does not overlap with the import $i$-goods of the product of the country $k$. Thus the possibility of establishing mutual exchange of commodity $i$ between countries $j$ and $k$ are minimal. If the value of index was maximal $\left(I_{c}=1\right)$, then there would be $X_{i j}=X_{i k}$, i.e. export of $i$-goods from the country $j$ would have the same relative significance as the import of the same commodity to the country $k$. Therefore, there would exist the possibility of establishing the trade of the commodity $i$ between the countries $j$ and $k$.

In case of interpreting the index values, we should be careful. Index value can be misleading, if the countries are geographically remote or if the difference in economies of the countries is big, i.e. if the relative and absolute significance of exchange do not match (agregation bias).

3. Coefficient of Conformity measures similarity of export (import) structure of two countries, i.e. to what extent the two countries analyzed are mutually competitive in the global market, as well as the possibility of their cooperation in entering the global market. Higher value of coefficients also implies higher level of competition between the economies of the two countries, i.e. greater similarity in the structure of their export (import). On the contrary, lower value of coefficients shows a diversity of export structure, lower level of mutual competition in the global market and potentially greater possibility of cooperation between economies in common presentation in the global market. 
Coefficient is calculated with the help of the following mathematical pattern:

$-C_{c}=\frac{\sum_{i=1}^{n} X_{i j} X_{i k}}{\sqrt{\sum_{i=1}^{n} X_{i j}^{2} \sum_{i=1}^{n} X_{i k}^{2}}}$

where the symbols used have the following meaning:

$X_{i j}$ - coefficient of the share of export (import) of the product $i$ in the total export (import) of the country $j, X_{i k}$ - coefficient of the share of export (import) of products $i$ in total export (import) of the country $k$.

Value of the coefficients is within the range $(0,1)$. Theoretically observed, extreme values of coefficient definition range imply complere diversity ( 0$)$ or complete conformity (1) of the structure of export (import) of the countries analyzed. If $C_{c}=0$, export (import) of the country $j$ equals zero in all commodity categories that are present in export (import) of the country $k$, i.e. that the country $k$ achieves export (import) equal to zero in all commodity categories which are present in export (import) of the country $j$. If $C_{c}=1$, each commodity category has equal share in export (import) of the country $j$ and in export (import) of the country $k$. Therefore, the greater is the difference between coefficients of share $\left(X_{i j}\right.$ and $\left.X_{i k}\right)$ by particular commodity categories, value of $C_{c}$ is closer to zero. It means that structures of export (import) of the countries $j$ and $k$ are incompatible. If the differences of coefficients are less, i.e. if their value is more equalized, value $C_{c}$ is closer to 1 , which confirms that the structures of export (import) of the countries $j$ and $k$ are more complement and the countries in the international market are in a sharper relationship of competition.

4. Regional Trade Intensity Index measures relative presence of the trade in a particular region (or between two countries) in relation to the global average. Therefore, coefficient is calculated as a ratio of the share of mutual export sum of the two countries in their total export and share of the total export of those two countries in the total global export:

$$
I_{t}=\frac{\frac{X_{i, j}+X_{j, i}}{\sum X_{i}+\sum X_{j}}}{\frac{\sum X_{i}+\sum X_{j}}{\sum X_{w}}}=\frac{\sum X_{w}\left(X_{i, j}+X_{j, i}\right)}{\left(\sum X_{i}+\sum X_{j}\right)^{2}}
$$

Where the symbols used have the following meaning:

$X_{i, j}$ - export from the country $i$ in the country $j ; X_{j, i}$ - export of the country $j$ in the country $i$; $\Sigma X_{i}$ - total export of the country $i ; \Sigma X_{j}$ - total export of the country $j ; \Sigma X_{w}$ total global export.

Value of the coefficients moves within the range from 0 to plus infinite. Lower value of coefficients occurs if mutual exchange of the observed countries is small. High value will occur as a consequence of big mutual exchange, and of little significance of export from both countries to other countries. Great value of the coefficients speaks of a high level of interdependence of the economies of two countries, as well as the compatibility of their economic structures. However, in case of coefficient value interpretation it is required to be careful. Increased exchange between the two countries can be the consequence of a series of political circumstances in the region they belong, rather than the consequence of economic advantages in relation to the trade with the rest of the world. 
5. Openness index (or the coefficient of trade dependence) measures the significance of international trade for entire economy of the country observed. In addition, with certain constraints, coefficient is the indicator of the level of openness for trade.

Coefficient is calculated by dividing the sum of export and import of one country by gross domestic product (GDP) of the country in the same period of time:

$$
O_{i}=\frac{\sum M+\sum X}{G D P}
$$

$\Sigma M$ - total export of the country $i$;

$\Sigma X$ - total import of the country $i$;

$G D P$ - total domestic product of $i$-country

Value of coefficients varies in the range from zero to plus infinity. These are, mainly theoretical values of coefficients, because minimal value would imply that it is about autarchic economy that neither exports nor imports and maximal (infinite) value that export or import do not affect the creation of GDP, i.e. that GDP equals zero.

Values of openness index is also affected by a great number of factors such as customs, noncustoms barriers, foreign exchange course, non-trade policies and economic structure of the country. All the factors mentioned affect the sum of trade transactions of the country analyzed. In addition, non-trade policies of country can affect the creation of big GDP, so that the country with a liberalized trade can have a relatively small value of coefficients. Low value of index can also be the consequence of trade restrictions in the country analyzed or foreign countries to the same country.

6. Main export product index is a simple measure of diversification of export to different sectors of economy. If none of the individual categories of export from one country does not exceed 50 or more percentage of the total export, economy of the country given is classified as diversified (diverse). Identification of the most significant products for the tarde of one country is useful for trade policy and management by adaptation.

Index of the main export product represents value of the greatest sectoral share of export in the total export of the country given:

$$
I_{m}=\frac{X_{i}}{\sum_{i=1}^{n} X_{i}} 100
$$

Where $X_{i}$ is the total export of the $i$-sector of the country given, and $\Sigma X_{i}$ is the total export of all the sectors of the given country.

Index value moves from 0 to 100 . In theory, if the index would have value 100 , it would mean that entire export of one country is only one sector, i.e. economy of that country would be non-diversified. Low value of the index for one sector speaks of a small significamce of its export for the total export. If all the export sectors have smaller value of the index of 50\%, the economy of the country in question is diversified.

Index value depends on the aggregation of data on the export. If we calculate the value of index for different years, the values obtained are comparable only under the condition of the same aggregation level. The same is applied for the comparison of the index value for two or more countries.

7. Hirschman's index of regional concentration measures geographic concentration of export. Index shows to what degree the export of one country or region is dispersed to different 
destinations. High concentration speaks of sensitivity of economic changes under the impact of small number of export market. In addition, alternatively, index can be observed also as the index of trade entropy.

Hirschman's index is calculated as a square root from square shares of export in particular countries in total export of the country observed.

$$
H_{i}=\sqrt{\sum s\left(\frac{\sum X_{j}}{\sum X_{n}}\right)^{2}}
$$

Where $\Sigma \mathrm{Xj}$ is the export of the country observed in j-country, $\Sigma \mathrm{Xn}$ total export of the country observed or its export in a particular region.

Index value moves within the range $(0,1)$. Less value marks greater dispersion of export of the country analyzed. Index value closer to 1 marks concentration of the total export of the country given on a smaller number of markets. If the index value is smaller, the impact of economic disorders (demand drop) from the countries where the country analyzed exports is less. Vice versa also stands. Of course, less value of the index implies less intensity of the impact of economic prosperity in exports country on the economy of the analyzed country and vice versa.

8. Export diversification index measures sectoral concentration of export by export regions. Index shows export dispersion level of a certain region or country through different economic activities. Index is calculated as a half of the sum of absolute values of difference between the share of the export of certain goods (group of products) in total export of the country and share of global export of the same product (group of products) in total global:

$$
I_{d}=\frac{1}{2}\left(\sum\left|\frac{X_{i j}}{\sum_{i} X_{e}}-\frac{X_{i w}}{\sum_{w} X_{e w}}\right|\right)
$$

The symbols used have the following meaning:

$X_{i j}$ - total export of $j$-commodity (group of products) from the country $i$,

$X_{e}-$ total export of the country $i$ in the period analyzed,

$X_{i w}$ - value of the total global export of $j$-commodity and

$X_{e w}-$ value of the total global export.

Value of export diversification index moves within the range $(0,1)$. If the coefficient value is 0 , it means that export from the country $i$ has the same relative significance as the export in the whole world. High value of the index shows a high level of dependence of the export of the country analyzed from a small number of products.

Calculation of the index can be done based on aggregated and non-aggregated data. If the data are aggregated, it is required to pay attention to the same level of aggregation for different periods of time or for the countries whose indexes are to be compared.

9. Sectoral index of intra-industrial trade represents the measure of the level by which the sector given affects intra-industrial trade in one country. By using the index given, we can affect the shaping of economic structure, i.e. the country can reduce the production of similar products and through the specialization it can increase the usage of the economy of scope in the production of differentiated products. Higher value of the index shows that the country given uses the effects of the economy of scope in the analyzed field of production. Vice versa also stands. 
Index value is obtained by substracting the ratio of the difference between export and import of one sector of economy (group of products) and the sum of export and import of the same economy sector (group of products) from the absolute value unit:

$$
I_{i t}=1-\frac{\left|\sum x_{i}-\sum m_{i}\right|}{\sum x_{i}+\sum m_{i}}
$$

where:

$\Sigma x_{i}$ - export of the given economy sector (group of products) and $\Sigma m_{i}-$ import of the given economy sector (group of products).

Index value moves within the range $(0,1)$. Minimal index value $(0)$ marks that the observed economy sector either only exports or imports, while at the same time there cannot be both export and import of the same products. Maximal index value (1) explains the situation in which the economy sector observed achieves the same value of export and import.

In case of interpreting the index values, we should be careful for many reasons. Value is calculated based on absolute value of export and import. Those data do not speak anything of the efficiency of domestic production and conjuncture in domestic market. If the change of index value is affected by the export, it can be the consequence of the growth of domestic consumption, as well as reduction of production of the given economy sector. In addition, in addition, the manner of data aggregation can have a great impact to the index value.

10. Trade overlap index. Indeks is a type of aggregate index of inter-industrial trade. It shows a relative significance of overlapping of intra-industrial trade in relation to the total intraindustrial profile of the trade of the economy given in the given period of time. In that aspect, index is a simpler manner of measuring aggregate intra-industrial trade.

Index is calculated as a double value of the ratio of the sum of minimal values of export and import of the sector of economy observed and total value of intra-industrial trade of the country given:

$$
I_{p t}=2 \times \frac{\sum \min \left(\sum x_{e}, \sum x_{i}\right)}{\sum X_{e}+\sum X_{i}}
$$

Where the symbols used have the following meaning: $\Sigma x_{e}$ - sum of the minimal values of export by economy sectors; $\Sigma x_{i}$ - sum of the minimal import values by economy sectors; $\Sigma X_{e}-$ total value of export of the country given in the time given and $\Sigma X_{e}$ - total value of the export of the country given in the time given.

Index value moves within the range $(0,1)$. Less value of the index marks that sectoral intraindustrial tarde has a relatively smaller significance in relation to the total intra-industrial trade. Maximal value of the coefficient implies equality of sectoral and aggregate intra-industrial trade.

In case of index application, particularly in comparative analysis, we should pay attention to the uniformity of the aggregation of data on export and import.

\section{RESULTS OF THE STUDY}

The analysis implemented represents the first fundamental analysis of mutual exchange and potential possibilitues of exchange between the economies of Srpska and Serbia based on the analysis of the similarity of economies, starting from the Agreement on establishment of special parallel relations and respecting the existing market structure (EIB, 2013). Although the period analyzed (2008-2012) is specific for the series of impacts of global economic crisis to the change 
of scope and structure of foreign trade exchange, the results of analysis implemented discover a series of specificities in mutual exchange of economies of Serbia and Srpska.

In the period analyzed, Serbian economy was the most important foreign trade partner for the economy of the Republic of Srpska. Economy of the Srpska has, on the average, exported to Serbia $18,13 \%$ of the total export, and imported $20,77 \%$ of the total import, which are the highest amounts with one foreign trade partner. Simultaneously, Serbian economy exported the most to $\mathrm{B} \& \mathrm{H}(10,91 \%$ of the total export), but, according to the significance of the value of the achieved import of Serbian economy, B\&H is at the 9 th place $(2,97 \%)$. The analysis carried out has shown that „Federacija of $\mathrm{B} \& \mathrm{H}$ in the foreign trade exchange with the Republic of Serbia has a more favourable position than the Republic of Srpska“" (EIB, 2013, pp. 64), which is precisely the consequence of a more favourable economic structure, diversity and differentiation of products. In addition, it confirms that the market does not function according to political commitments, but according to economic motives of the participants. From the aspect of Linder hypothesis, it is an expected conclusion because the structure of demand between B\&H and Serbia is more complementary than the structure of demand between Serbia and Srpska.

Next we will show basic results of similarities and interdependences of economies of Serbia and Srpska, and explain their implications for the total economic cooperation and establishment of parallel relations.

Similarity of import and export structure. Defined values of Finger-Kreinin index for the period 2008-2012. (average 45,88) confirm a relatively high similarity level of the export structures economies of Serbia and Srpska. In fact, value of the index is far beyond the identical structure (100), but it is significant. Similar thing is with the structure of import, although the index value is higher (average 68,13).

Complementarity of foreign trade exchange. One of the significant indicators for establishment of foreign trade cooperation of the two economies, complementarity index of foreign trade exchange, shows extremely high value for a great number of products (average value 0,9012). Calculating based on average values of export and import in the period analyzed, complementarity index had the value 0,92 for the export of Serbia and 0,95 for the export of the Republic of Srpska.

Conformity of export. Additional verification of data on relatively high level of competition between Srpska and Serbia in the third markets was verified by the coefficient of conformity of the export. Based on it, we have determined the measure of the competition level between the exporters. In the period analyzed, coefficient had the average value 87,63 which testifies on sharp competition of exporters from Srpska and Serbia in the markets of the third countries.

Regional trade intensity. The possibility of a much greater mutual foreign trade exchange of Serbia and Srpska is also pointed by the movement of the value of regional trade intensity index. Average value of this index in the period analyzed (2008-2012) was 97,98 (it is possibile to go plus infinity), with the tendency of drop from 2008. (115,35) to 2012. (80,75).

Openness of economies. One of the significant measurements for setting the strategy of trade cooperation of the two economies is economy openness index or trade dependence index which measures the significance of international trade for the economy of one country. In the period analyzed, both Srpska and Serbia had a high value of openness index. Average value for Srpska was 0,75 and for Serbia 0,71 .

Diversification of economies. By the analysis of main export product it was determined that both economies have a high diversification level. Average value of economy diversification index in the period analyzed for Serbia was 5,6 and for the Republic of Srpska 9.

Regional concentration of export. Index of regional concentration of export (Hirschman's index) for both economies in the whole period analyzed shows a stable movement and a relatively 
low value. Average value for Srpska was 0,32 (one third from the maximal value), and for Serbia 0,25 (one fourth of the maximal value).

Export diversification. Value of export diversification index in the period analyzed for both economy is relatively high, particularly for Srpska. In the period 2008-2012., export diversification index for Srpska had the average value of 0,58 (maximally 1, and desirable 0), and for Serbia 0,41 .

Intra-industrial trade. The same geographical location of economies, similar level of economic development and similar problems of economic and social development of the two economies impose the need for analysis of intra-industrial trade. Based on the mentioned parameters, it was expected for Serbia and Srpska to have a high level of intra-industrial trade. Values obtained of intra-industrial trade index for the period from 2008. to 2012. Partially confirm previous expectation. Namely, in most activities, intra-industrial trade index is higher than zero for both economies, which means that there is intra-industrial trade. The highest values of index were achieved precisely in activities that are most significant for foreign trade exchange of both countries: manufacturing industry $(0,81$ - Serbia, 0,73 - Srpska), agriculture $(0,83-$ Serbia, 0,55 - Srpska) and production and supply of electricity (0,97 - Serbia, 0,49 - Srpska).

Overlapping of trade. The observed characteristics of mutual foreign trade relations based on the values of intra-industrial trade index are also confirmed based on the trade overlapping index (sector index of intra-industrial trade). Average value of this index in the period analyzed (2008-2012) was for Srpska 0,38 and for Serbia 0,5.

\section{CONCLUSION}

Complementarity and similarity of economies of Srpska and Serbia are not valorized from the aspect of Agreement on special parallel relations and they were never crucial for setting common strategy in development of certain activities or joint presentation of two economies in third markets.

Relatively high level of similarity of the export structure shows that exporters from Srpska and Serbia are often competitors in the third markets. The greatest impact to similarity of export structure has the import within manufacturing industry (production of food products, production of base metals, production of finished metal products) which is of a special significance for the development of both economies. Value of the trade conformity coefficient in the period analyzed $(87,63)$ confirms that exporters from Serbia and exporters from Srpska are severe competitors in the markets of the third countries. Markets of the third countries where the exporters from both economies dictate the competition level and do not tollerate any form of common presentation that would impair the competition.

The analysis has confirmed high conformity of the structure of export of Srpska and import of Serbia and vice versa, i.e. a great number of products that are exported by the economy of Srpska are simultaneously imported by Serbia and a great number of products exported by Serbia are simultaneously imported by Srpska. Accordingly, there are big potential possibilities for establishing a broad cooperation between two economies in the production of a series of goods and providing services in different activities. From the relative aspect, there are big potential possibilities of complementarity of two economies, although, from the aspect of absolute values, mutual exchange level in a series of activities is small, i.e. potential possibilities are not used. Insufficient utilization of complementarity of economies comes from a low level of industrial production, relatively small export and limited possibilities of consumption in both economies.

Although there are big potential possibilities for economic cooperation, Srpska and Serbia have a relatively small foreign trade exchange and a relatively small economic dependence of the 
two economies. Practically, both economies are unsustainable as autarcgic economies in the existing form. Therefore, dependence of the economy of Srpska from foreign trade is greater than in case of Serbian economy. In addition, having in mind that Serbia is the most significant foreign trade partner of Srpska, dependence of the economy of Srpska from the trade with Serbia is much greater than the dependence of Serbian economy from the economy of Srpska. It means that Srpska should pay a relatively greater attention to foreign trade system and policy, particularly when it is about bilateral tarde between B\&H and Serbia, including the initiation of regulating stimulation conditions for cooperation between the companies from the two countries, as well as regulation of favorable bilateral relations between B\&H and Serbia as a general framework for economic cooperation. This we will obtain the assumptions for verification of all other advantages of mutual economic cooperation.

Both economies have a high level of economy diversification. That reduces their sensitivity to the disorders in the global market and reduces the chances for causing damage to bilateral trade due to foreign disorders. In facts, a high economy diversification level imples a low level of specialization in the export, which can affect the reduction of efficiency of particular government measures in encouraging and promotion of export economy. A high level of diversification of both economies reduce potential possibilities for their cooperation.

Both economies, particularly the economy of Srpska, have a high level of dependence of the achieved value of export from the import of relatively small number of products, significantly less than average in the global trade. Thus they are significantly more sensitive to the demand drop in the global market for the products dominant in the structure of their export. High diversification of economy and small diversification of export point to a high level of innovations in development of products and their differentiation. Both economies have the need for increasing the scope and value of export of a greater number of competitive products, i.e. they have the need for export diversification. Without innovation and differentiation of products, in conditions of high diversification of economy, motivation for foreign trade exchange gets weaker.

Value of the export achieved is more regionally concentrated in Srpska than Serbia, which is logical having in mind the size of economy and the fact that Serbia if the most significant foreign trade center for Srpska. Value of Hirschman's index shows that both economies were not exposed to a high risk due to too high concentration of export. However, that form of security is not particularly desirable in countries with a high deficit of pay balance, which is the case with B\&H and Serbia. For both economies, there would be a greater benefit to have an increase of export with a higher value of Hirschmanćs index, because higher regional concentration of export also implies a greater openness towards the prosperity in countries to which it is exported. The existing level of regional concentration of export of Srpska and Serbia is not an obstacle to their more extensive foreign trade cooperation.

Trade between the same sectors of the two economies (intra-industrial) has the great significance for foreign trade cooperation. Serbia has greater values of the intra-industrial (internal sector) trade index, which is understandable having in mind the size of economy, higher level of coverage of import by export and greater competitiveness of Serbian economy. General level of intra-industrial exchange is relatively high. However, in a series of activities, intra-industrial trade index has a low value for both economies, which means that products of those activities are mainly imported or exported. Therefore, a part of the trade by a relatively great number of products between Srpska and Serbia is based mainly on comparative advantages of production which de facto represents inter-industrial trade, which is a characteristic of a lower level of economic development and foreign trade cooperation. This fact also points out that a low level of finalization and differentiation of products in agreat number of activities has a destimulation effect on the increase of scope of mutual economic cooperation of the economies of Serbia and Srpska. This is also confirmed by a relatively low value of trade overlapping index, particularly for Srpska, which means that sectoral intra-industrial exchange deviates from general 
intra-industrial exchange, i.e. at the exchange sector level there is a little number of differentiated products exchanged, which is a characteristic of unjagged structure of supply, insufficient development of exchange, low competitiveness, insufficient usage of the economy of scope in mutual economic cooperation and low level of applying innovations in product development.

From the aspect of Linder hypothesis, we can conclude that two economies, in addition to the fact of being significant foreign trade partners to each other, have great possibilities for the increase of mutual economic cooperation. The logic of Linder hypothesis leads to conclusion that Serbia and Srpska should increase specialization in production, i.e. reduce diversification of economy and incraese diversification of export. The basis for such an approach is the increase of innovations in creation and differentiation of products.

Both countries have small share of the „exchanged“ part in gross domestic product (Labus, Milošević, 2009; Tomaš, 2012) and, due to stability of economy, it will have to increase the share of manufacturing industry in gross domestic product and increase the export in the future. Both economies, and particularly the economy of Srpska, insufficiently use the economy of scope in production, as well as innovations in the process of product differentiation. In that field that are significant possibilities for the increase of intra-industrial trade of the two economies, where they would become more rational, competitive and with more features of modern development. Both economies do not export sufficientlt, so high level of export diversification does not represent a great advantage. The export of a great number of products in relatively small amount and small value is often not economically the most rational choice.

European integration of B\&H and Serbia, particularly because both B\&H and Serbia see their future in European Union. Membership in CEFTA and implementation of the Agreement on process of stabilization and joining give a more complete sense to the Agreement on establishment of special parallel relations, spreading institutional capacity of its implementation and adding mutual cooperation of Serbia and Srpska the dimension of regional and European integration of B\&H and Serbia.

The economy of Srpska functions in the framework of foreign trade system and policy that are regulated within the institutions of B\&H. However, membership in CEFTA and openning the process of integration in EU significantly unifies the system, policy and practice of foreign trade exchange of member countries. In that aspect, Srpska has the interest to advocate within B\&H institutions for regulation of bilateral relations with Serbia that enable the realization of Agreement on special and parallel relation, as well as to contribute itself and require from B\&H the implementation of the obligations taken from CEFTA and Agreement on the process of stabilization and joining. It is of a special importance for the economy of the Republic of Srpska and its greater contribution to the implementation of the economic aspect of the Agreement on establishment of special relations is strengthening of cooperation with the companies from $\mathrm{B} \& \mathrm{H}$ Federation. Through that cooperation, we can increase the competitiveness and the level of differentiaton of products which would extend the possibilities of greater exchange with the companies from Serbia. Political pressures to establishment of economic exchange of the companies from Srpska with companies from Serbia are meaningless and economically harmful.

\section{REFERENCES}

1. Bukhari, S.A.H.A.S., Ahmad, M.H., Alam, S., Bukhari, S.S.H.A.S. and Butt, M.S., (2005). An Empirical Analysis of the Linder Theory of International Trade for South Asian Countries, The Pakistan Development Review Vol. 44: No 3 (Autumn 2005) pp. 307-320, Available from: https://www.researchgate.net/publication/242117439, 20.04.2018 
2. EIB (Economic Institute Banja Luka) (2013). Sličnost i komplementarnost privredne strukture Republike Srpske i Republike Srbije kao osnove jačanja ekonomske saradnje (Similarity and complementarity of economic structure of the Republic of Srpska and the Republic of Serbia as a basis for strengthening economic cooperation), Banja Luka

3. European Commission, (2009). The Western Balkans in Transition, European Economy, Occasional Papers 46, Brussels

4. Fajgelbaum, P.D., Gene M. Grossman, G.M., and Helpman, E., (2014). A Linder Hypothesis for Foreign Direct Investment, NBER Working Paper No. 17550, Issued in October 2011, Revised in August 2014, http://www.nber.org/papers/w17550, 14.05.2018

5. Finger, J. M. and Kreinin, M. E., (1979). "A Measure of 'Export Similarity' and Its Possible Uses," Economic Journal, Royal Economic Society, vol. 89(356), pages 905-912, December.

6. Hallak, J.C., (2010). Aproduct-Quality View of the Linder Hypothesis, The Review of Economics and Statistics, Vol. XCII, No. 3, pp. 453-466.

7. Kahram, A., (2014). The Comparative Analysis of the Linder Hypothesis:The Bilateral Trade Model between Iran and Its Trade Partners, Advances in Economics and Business Management (AEBM), Print ISSN:_2394-1545; Online ISSN: 2394-1553; Volume 1, Number 1; November, 2014 pp. 1 - 8 (C) Krishi Sanskriti Publications http://www.krishisanskriti.org/aebm.html , 12.4.2018

8. Kathuria, S., (2008). Western Balkan Integration and the EU: An Agenda for Trade and Growth, World Bank, Washington DC.

9. Labus, M. i Milošević, S., (2009). Ekonomska kriza u Srbiji: Izmedju rasta i strukturnih promena, „Rast u uslovima globalne recesije i finansijske krize: (ne)konvencionalne inicijative, Udruženježenje korporativnih direktora Srbije, Kopaonik biznis forum 2009

10. Leontief, W. W., (1953). Domestic Production and Foreign Trade: The American Capital Position Re-examined. Proceedings of the American Philosophical Society, Vol. 97, No. 4 (Sep. 28, 1953), pp. 332-349, https://www.jstor.org/stable/3149288?newaccount=true\&readnow=1\&seq=1\#page_scan_tab_contents, 12.4.2018

11. Linder, S. B., (1961). An Essay on Trade and Transformation, ALMQVIST \& WIKSELLS, BOKTRYCKERI AB, UPPSALA, 1961, https://ex.hhs.se/dissertations/221624FULLTEXT01, 12.4.2018

12. Madžar, M. i drugi, (2000)., Ekonomska integracija na teritoriji bivše Jugoslavije - na putu ka evropskoj integraciji, Ekonomski institut Beograd

13. Mcpherson, M.A., Redfearn, M.R., and Tieslau, M.A. (2006). A Re-Examination of the Linder Hypothesis: A Random-Effects Tobit Approach, International Economic Journal, Vol. 14, No. 3, pp. 123-136, DOI: 10.1080/10168730000000032, 12.4.2018

14. Mikic, M. and Gilbert, J., (2007). Trade Statistics in Policymaking, A Handbook of Commonly Used Trade Indices and Indicators, United Nations publication, Economic and Social Commission for Asia and Pacific

15. Moraliyska, M., (2015). Regional Economic Cooperation in the Western Balkans and Its Impact on Bulgaria, Economic Alternatives, Issue 1, 2015, pp. 100-117.

16. Niem, L.D., (2016). Linder Hypothesis and Trade of Quality Differentiated Good: A Case of Cosmetic Industry of China, Modern Economy, 7, 307-313.

http://dx.doi.org/10.4236/me.2016.73033,

https://www.researchgate.net/publication/299406222_Linder_Hypothesis_and_Trade_of_Q uality_Differentiated_Good_A_Case_of_Cosmetic_Industry_of_China , 14.05.2018 
17. Penev, S., A. Marusic, (2011). Progress in Transition and Reform Implementation in Serbia Comparing to other Western Balkan Countries, with Main Focus on Regulatory Reform (2011), IFC, World Bank Group, Washington DC

18. Penev, S., (2013). Economic and European perspectives for the Western Balkan countries, Institut ekonomskih nauka, Beograd

19. Rauh, A., (2010). Empirical Analysis of the Linder Hypothesis: The Case of Germany's Trade Within Europe, The American Economist, Volume: 55, No 2, page(s): 136-141, Article first published online: September 1, 2010; Issue published: November 1, 2010, https://doi.org/10.1177/056943451005500214, 20.04.2018

20.Seyedmashhadi, P.A.4,Seyed Abdolmajid Jalaee, S.A.,Nejati, M., Zayanderodi, M. (2017).,,Examining and comparing the economic effects of spillovers of investment risk inIran: Computable General Equilibrium Model Approach,, International Review 3-4/2017, ISSN 2217 9739, p.25,Faculty of Business Economics and Entrepreneurship, Belgrade, Serbia

21. Sailors, J.W, Usman A. Qureshi, U.A., Cross, E.M., (1973).Empirical Verification of Linder's Trade Thesis, Southern Economic Journal, Vol. 40, No. 2 (Oct., 1973), pp. 262 268, Published by: Southern Economic Association, DOI: 10.2307/1056877, Stable URL: http://www.jstor.org/stable/1056877, 20.04.2018

22. Standard International Trade Classification (SITC Revision 3, 1988, https://joinup.ec.europa.eu/solution/scl-standard-international-trade-classification-sitc-rev3$1988,6.6 .2018$

23. Steinbach, S., (2015). Bilateral export trade and income similarity: Does the Linder hypothesis hold for agricultural and foodtrade?, Swiss Federal Instute of Technology, Zurich, https://www.google.ba/search?q=Sandro+Steinbach $\% 2 \mathrm{C}+$ Bilateral+export+trade+and+inco me+similarity $\% 3 \mathrm{~A}+$ Does+the+Linder+hypothesis+hold+for+agricultural+and+foodtrade $\% 3$ F\%2C\&oq=Sandro+Steinbach\%2C+Bilateral+export+trade+and+income+similarity\%3 A+ Does+the+Linder+hypothesis+hold+for+agricultural+and+foodtrade $\% 3 \mathrm{~F} \% 2 \mathrm{C} \&$ aqs $=$ chrome ..69i57.1116j0j7\&sourceid=chrome\&ie=UTF-8, 10.05.2018

24. Stojković, D., (2012). Integracioni procesi berzi sa područja bivše SFRJ i regionalna saradnja Beogradske berze, Bankarstvo 2012, vol. 41, br. 2, str. 34-51

25. Tomaš, R., (2012). Limited Possibilities of Adapting the Economy of Bosnia and Herzegovina to the External Pressures of the Economic Crisis, Acta Economica, Volume X, No. 17, pp. 9-30, DOI:10.7215/ACE1217009T

\section{Article history:}

- Received 20 October 2018

- Accepted 10 December 2018 